attainments, Prof. V. Ball is also known by his papers on various ethnological subjects. This appointment will leave the Chair of Geology and Mineralogy in the University of Dublin vacant after next Michaelmas Term.

THE Improvement Commissioners of Bournemouth, at a meeting on Tuesday, discussed the desirability of inviting the British Association to visit Bournemouth. It was unanimously decided to invite it for 1885 .

THE last news received by the Russian Geographical Society from the Lena meteorological station is dated April 3. The observers have suffered to some extent from the hard winter, and especially from the winds, and it was with difficulty that they succeeded in maintaining a moderate temperature in their house. Still they were all in good health. The lowest temperature observed was $-52^{\circ} \cdot 3$ Celsius on February 9. In January and February it usually did not fall below $-40^{\circ}$, excepting during quite calm weather. In March the thermometer oscillated about $-40^{\circ}$, and at the beginning of April it began to rise to $-19^{\circ}$. M. Yurgens found great difficulties with the magnetic instruments, the range of deviation of the needles during the magnetic perturbations being as much as $25^{\circ}$ from the magnetic meridian, and those which measure the horizontal intensity ${ }_{5}$ howing deviations of as much as $90^{\circ}$.

THE subterranean rooms of the Paris Observatory are ready for the receptior of the magnetic instruments. Three sets will be arranged-one for registering, the second for direct observation as established by Lamont at Munich, and the third will be composed of the old instruments used by Arago for comparing the numbers taken in former times.

Circumstances, says Science, were not favourable to the production of remarkable essays at the recent meeting of the American Association. The attendance was not large. The officers of the meeting, and especially those who had to make addresses, could scarcely be expected to produce elaborate papers in addition to their other labours. As the number of addresses per meeting has increased, we may observe more ireadily some of the effects of the system that demands them. The most evident result is that usually where we gain one good address we lose two or three good papers. The distance of the meeting from their homes affected especially members of Sections A, B, C, and $\mathrm{D}$, devoted to the exact sciences. Perhaps it affected the quality as well as the number of their papers. There were not many from the east to present essays, though quite as many as could have reasonably been expected; but there were scarcely any from the locality of the meeting and its neighbourhood. Local interest, both as to authors and hearers, was of course deficient. In short, there was nothing remarkable in those sections to spur production, and the product was not remarkable. It was good, but not great.

THE fourth annual "Cryptogamic Meeting" of the Essex Field Club will take place in Epping Forest on Saturday, September 29. A large number of botanists have promised to be present and act as referees. In the evening a meeting for the exhibition of botanical specimens will be held in the Assembly Room at the "Rnebuck" Hotel, Buckhurst Hill, when the following papers will be read :- " Recent Additions to the Fungus Flora of Epping Forest," by Dr. M. C. Cooke, M.A., F.L.S.; "The "Lower Orders' of Fungi," by Worthington G. Smith, F.L.S.; "Fungi as Poisons," by Dr. Wharton, M.A., F.L.S. Botanists wishing to attend the meeting or to exhibit specimens should communicate with the Hon. Secretary, Mr. W. Cole, Buckhurst Hill, Essex.

Mr. Srmmons and a companion left Hastings in a balloon at 3.20 p.m. on Thursday last, and landed in about seven hours at Cape La Hogue, in France.
THE additions to the Zoological Society's Gardens during the past week include two Chinese Rhesus Monkeys (Macacus lasiotus $\delta$ q) from China, presented by Mr. G. A. Conder ; a Pig. tailed Monkey (Macacus nemestrinus $\delta$ ) from Java, presented by Mr. Robert Smith; a Hog Deer (Cervus porcinus o) from India, presented by Mr. D. Charles Horne; a Snow Bunting (Plectrophanes nivalis), European, presented by Mr. E. J. Gibbins; two Ring Doves (Columba palumbus), British, presented by Mrs. Courage; two Land Rails (Crex pratensis), British, presented by Dr. Marshall ; a Robben Island Snake (Coronella phocarum), a Rufescent Snake (Leptodira rufescens), a Ring-hals Snake (Sepeton hamachetes) from South Africa, presented by the Rev. G. H. R. Fisk, C.M.Z.S.; a Grey Sezl (Halicharus sryphus) fro'n Cornwall, two Margined Tortoises (Testudo marginata), South European, a Glass Snake (Pseudopus pallasi) from Dalmatia, deposited.

\section{A PLEA FOR PURE SCIENCE 1}

I AM required to address the so-called Physical Section of this Association. Fain would I speak pleasant words to you on this subject; fain would $I$ recount to you the progress made in this subject by my countrymen, and their noble efforts to understand the order of the universe. But I go out to gather the grain ripe to the harvest, and I find only tares. Here and there a noble head of grain rises above the weed; ; but so few are they that I find the majority of my countrymen know them not, but think that they have a waving harvest, while it is only one of weeds after all. American science is a thing of the future, and not of the present or past ; and the proper course of one in my pocition is to consider what must be done to create a science of physics in this country, rather than to call telegraphs, electric lights, and such conveniences by the name of science. I do not wish to underrate the value of all these things: the progress of the world depends on them, and he is to be honoured who cultivates them successfully. So also the cook who invents a new and palatable dish for the table, benefits the world to a certain degree ; and yet we do not dignify him by the name of a chemist. And yet it is not an uncommon thing, especially in American newspapers, to have the applications of science confounded with pure science; and some obscure American who steals the ideas of some great mind of the past and enriches himself by the application of the same to domestic uses, is often lauded above the great originator of the idea, who might have worked out hundreds of such applications had his mind possessed the necessary element of vulgarity. I have often been asked which was the more important to the world, pure or applied science. To have the applications of a science, the science itself must exist. Should we stop its progress and attend only to its applications, we should soon degenerate into a people like the Chinese, who have made no progress for generations, because they have been satisfied with the applications of science, and have never sought for reasons in what they have done. The reacons constitute pure science. They have known the application of gunpowder for centuries; and yet the reasons for its peculiar action, if sought in the proper manner, would have developed the science of chemistry, and even of physics, with all their numerous applications. By contenting themselves with the fact that gunpowder would explode, and seeking no further, they have fallen behind in the progress of the world; and we now regard this oldest and most numerous of nations as only barbarians. And yet our own country is in this same state. But we have done better; for we have taken the science of the Old World and applied it to all our uses, accepting it like the rain of heaven, without asking whence it came, or even acknowled ging the debt of gratitude we owe to the great and unselfish workers who have given it to us. And, like the rain of heaven, this pure science has fallen upon our country, and made it great and rich and strong.

To a civilised nation of the present day the applications of science are a necessity; and our country has hitherto succeeded in this line only for the reason that there are certain countries in the world where pure science has been and is cultivated, and where the study of nature is considered a noble pursuit. But such countries are rare, and those who wish to pursue pure

${ }^{x}$ Condensed abstract of the adi-ess of Prof. H. A. Rowland of Baltimore, vice-president of Section $\mathrm{B}$ (Physics), before the American Association at

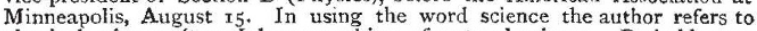
physical science," as I know nothing of natural science. Probably my remarks will, however, apply to both, but I do not know." 
science in our own country must be prepared to face public opinion in a manner which requires much moral courage. They must be prepared to be looked down upon by every successful inventor whose shallow mind imagires that the only pursuit of mankind is wealth, and that he who obtains most has best succeeded in this world. Everybody can comprehend a million of money ; but how few can comprehend any advance in scientific theory ; especially in its more abstruse portions! And this, I believe, is one of the causes of the small number of persons who have ever devoted themselves to work of the higher order in any human pursuit. Man is a gregarious animal, and depends very much, for his happiness, on the sympathy of those around him; and it is rare to find one with the courage to pursue his own ideals in spite of his surroundings. In times past, men were more isolated than at present, and each came in contact with a fewer number of people. Hence that time constitutes the period when the great sculptures, paintings, and poems were produced. Each man's mind was comparatively free to follow its own ideals, and the results were the great and unique works of the ancient masters. To-day, the railroad and the telegraph, the books and newspapers, have united each individual man with the rest of the world : in tead of his mind being an individual, a thing apart by itself, and unique, it has become so influenced by the outer world, and so dependent upon it, that it has lost its originality to a great extent. The man who in times past would naturally have been in the lowest depths of poverty, mentally and physically, to day measures tape behint a counter, and with lordly air advises the naturally born genius how he may best bring his cutward appearance down to a level with his own. A new idea he never had, but he can at least cover his mental nakedness with ideas imbibed from others. So the genins of the past soon perceives that his higher ideas are too bigh to be appreciated by the world: his mind is clipped down to the standard form ; every natural offshoot mpwarts is repressed, until the man is no higher than his fellows. Hence the world, through the abundance of its intercourse, is reduced to a level. What was formerly a grand and magnificent landscape, with mountain ascending atove the clouds, and depths whose gloom we cannot now appreciate, has become serene and peaceful. The depth have been filled, and the heights levelled, and the wavy harvests and smoky factories cover the landscape.

As far as the average man is concerned, the change is for the better. The average life of man is far pleasanter, and bis mental condition better, than before. But we miss the vigcur imparted by the mountains. We are tired of mediocrity, the curse of our country. We are tired of seeing our artists reduced to hirelings, and im loring Congress to protect them against foreign competition. We are tired of seeing our countrymen take their science from abroad, and boast that they here convert it into wealth. We are tired of secing our professors degrading their chairs by the pursuit of applied science instead of pure science; or sitting inactive while the whole world is open to investigation; lingering by the wayside while the problem of the universe remains unsolved.

For generations there have been some few students of science who have esteemed the study of nature the most noble of pursuits. Some have been wealthy, and some poor; but they have all had one thing in common-the love of nature and its laws. To these few men the world owes all the progress due to applied science, and yet very few ever received any payment in this world for their labours.

But there will be those in the future, as well as in the past, who will do so; and for them higher prizes than any yet obtained are waiting. We have but yet commenced our pursuit of science, and stand upon the threshold wondering what there is within. We explain the motion of the planet by the law of gravitation; hut who will explain how two bodies, millions of miles apart, tend to go toward each other with a certain force?

We now weigh and measure electricity and electric currents with as much eare as ordinary matter, yet have we made any approach to an explanation of the phenomenon of electricity? Light is an undulatory motion, and yet do we know what it is that undulates? Heat is motion, yet do we know what it is that moves? Ordinary matter is a common substance, and yet who shall fathom the mystery of,its internal constitution?

How shall we, then, honour the few, the very few, who, in spite of all difficulties, bave kept their eyes fixed on the goal, and have steadily worked for pure ccience, giving to the world a most precious donation, which bas borne fruit in our greater knowledge of the universe and in the applications to our physical life which have enriched thcusands ard benefited each one of us? There are also those who have every facility for the pursuit of science, who have an ample salary and every appliance for work, yet who devote themselves to commercial work, to testifying in courts of law, and to any other work to increase their present large income. Such men would be respectable if they gave up the name of professor, and took that of consulting chemists or physicists. And such men are needed in the community. But for a man to occupy the professor's chair in a prominent college, and, by his energy and ability in the commercial applications of his science, stand before the local community in a prominent manner, and become the newspaper exponent of his science, is a disgrace both to him and his college. It is the deathblow to science in that region. Call him by his proper name, and he becomes at once a useful member of the community. Put in his place a man who shall by precept and example cultivate his science, and how different is the result! Young men, looking forward into the world for something to do, see before them this high and noble life, and they see that there is something more honourable than the accumulation of wealth. They are thus led to devote their lives to similar pursuits, and they honour the professor who has drawn them to something higher than they might otherwise have aspired to.

I do rot wish to be misunderstood in this matter. It is no disgrace to make money by an invention, or otherwise, or to do commercial scientific work under some circumstances. But let pure science be the aim of those in the chairs of professors, and so prominently the aim that there can be no mistake. If our aim in life is wealth, let us honestly engage in commercial pursuits and compete with others for its possession. But if we choose a life which we consider higher, let us live up to it, taking wealth or poverty as it may chance to come to us, but letting neither turn us aside from our pursuit.

The work of teaching may absorb the energies of many; and indeed this is the excuse given by most for not doing any scientific work. But there is an old saying that where there is a will there is a way. Few professors do as much teaching or lecturing as the German professors, who are also noted for their elaborate papers in the scientific journals. A university should not only have great men on its faculty, but bave numerous minor professors and assistants of all kinds, and should encourage the highest work, if for no other reason than to encourage the student to his highest efforts. But, assuming that the professor bas high ideals, wealth such as only a large and high university can command is necessary to allow him the fullest development.

And this is specially so in our science of physics. In the early days of physics and chemistry many of the fundamental experiments could be performed with the simplest apparatus. And so we often find the names of Wollaston and Faraday mentioned as needing scarcely anything for their researches. Much can even now be done with the simplest apparatus; and nobody, except the utterly incompetent, need stop for want of it. but the fact remains that one can only be free to investigate in all departments of chemistry and physics, when he not only has a complete laboratory at his command, but a friend to draw on for the expenses of each experiment. That simplest of the departments of physics, namely, astronomy, has now reached such perfection that nobody can expect to do much more in it without a perfectly equipped observatory ; and even this would be useless without an income sufficient to employ a corps of assistants to make the observations and computations.

But would it not be possible to so change public opinion that no college could be founded with a less endowment than say $\mathbf{I}, 000,000$ dollars, or no university with less than three or four times that amount?

The total wealth of the 400 colleges and universities was in I 880 about $40,000,0 \mathrm{co}$ dollars in buildings, and 43, 000,000 dollars in productive funds. This would be sufficient for one great university of $10,000,000$ dollars, four of $5,000,000$ dollars, and twenty-six colleges of $2,000,000$ dollars each. But such an idea can of course never be carried out. Government appropriations are out of the question, because no political trickery must be allowed around the ideal institution.

In the year 1880 the private bequests to all schools and colleges amounted to about $5,500,000$ dollars. We must make the need of research and of pure science felt in the country. We must live such lives of pure devotion to our science, that all shall see that we ask for money, not that we may live lives of indolent ease at the expense of charity, but that we may work for that which has advanced and will advance the world more than any other subject, both intellectually and physically. We must live 
such lives as to neutralise the influence of those who in high places have degraded their profession, or have given themselves over to ease, and do nothing for the science which they represent. Let us do what we can with the present means at our disposal. There is not one of us who is situated in the position best adapted to bring out all his powers, and to allow him to do most for his science. All have their difficulties, and I do not think that circuinstances will ever radically change a man. If a man has the instinct of research in him, it will always show itself in some form.

I do not believe anybody can be thorough in any department of science, without wishing to advance it. In the study of what is known, in the reading of the scientific journals, and the discussions therein contained of the current scientific questions, one would obtain an impulse to work, even though it did not before exist. And the same spirit which prompted him to seek what wa- already known, would make him wish to know the unknown. And 1 may say that I never met a case of thorough knowledge in my own science, except in the case of well-known investigators. I have met men who talked well, and I have sometimes asked myself why they did not do something; but further knowledge of their character has shown me the superficiality of their knowledge.

What would astronomy have done without the endowments of observatories? By their means, that science has become the most perfect of all branches of physics, as it should be from its simflicity. There is no doubt, in my mind, that similar institutions for other branches of physice, or, better, to include the whole of physice, would be equally successful. A large and perfectly equipped physical laboratory, with its large revenues, its corps of professors and assistants, and its machine-shop for the construction of new apparatus, would be able to advance our science quite as much as endowed observatories have astronomy. But such a laboratory should not be founded rashly. The value will depend entirely on the physicist at its head, who has to devise the plan, and to start it into practical working. Such a man would be always rare, and could not always be obtained. After one had been successfully started, others could follow; for imitation requires little brains.

One could not be certain of getting the proper man every time, but the means of appointment should be most "carefully studied so as to secure a gord average. There can be no doubt that the appointment should rest with a scientific body capable of judging the highest work of each candidate. Should any popular element enter, the person chosen would be either of the literary-scientific order, or the dabbler on the outskirts who presents his small discoveries in the most theatrical manner. What is required is a man of depth, who has such an insight into physical science that he can tell when blows will best tell for its advancement.

Such a grand laboratory as I describe does not exist in the world, at present, for the study of physics. But no trouble has ever been found in obtaining means to endow astronomical science. Everybody can appreciate, to some extent, the value of an observatory; as astronomy is the simplest of scientific subjects, and has very quickly reached a position where elaborate instruments and costly computations are necessary to further advance. The whole domain of physics is so wide that workers have hitherto found enough to do. But it cannot always be so, and the time has even now arrived when such a grand laboratory should be founded. Shall our country take the lead in this matter, or shall we wait for foreign countries to go before? They will be built in the future, but when and how is the question.

As stated before, men are influenced by the sympathy of those with whom they come in contact. It is impossible to immediately change public opinion in our favour; and, indeed, we must always seek to lead it, and not be guided by it. We must create a public opinion in our favour, but it need not at first be the general public. We must be contented to stand aside, and see the honours of the world for a time given to our inferiors ; and must be better contented with the approval of our own consciences, and of the very few who are capable of judging our work, than of the whole world beside. Let us look to the other physicists, not in our own town, not in our own country, but in the whole world, for the words of praise which are to encourage us, or the words of blame which are to stimulate us to renewed effort. For what to us is the praise of the ignorant? Let us join together in the bonds of our scientific societies, and encourage each other, as we are now doing, in the pursuit of our favourite study; knowing that the world will some time recognise our services, and knowing, also, that we constitute the most important element in human progress.

But danger is also near, even in our societies. When the average tone of the society is low, when the highest honours are given to the mediocre, when thind-class men are held up as examples, and when trifing inventions are magnified into scientific discoveries, then the influence of such societies is prejudicial. A young scientist attending the meetings of such a society soon gets perverted ideas. To his mind a molebill is a mountain, and the mountain a molehill. The small inventor or the local celebrity rises to a greater beight, in hi- mind, than the great leader of science in some foreign land. He gauges himself by the molehill and is satisfied with his stature; not knowing that he is but an atom in comparison with the mountain, until, perhaps, in old age, when it is too late. But, if the size of the mountain had been seen at first, the young scientist would at least have been stimulated in his endeavour to grow.

We ca?", this a free country, and yet it is the only one where there is a direct tax upon the pursuit of science. The low state of pure science in our country may possibly be attributed to the youth of the country; but a direct tax to prevent the growth of our country in that subject cannot be looked upon as other than a deep disgrace. I refer to the duty upon foreign books and periodicals. One would think that books in foreign languages might be admitted free; but to please the half-dozen or so workmen who reprint German books, not scientific, our free intercourse with that country is cut off.

The time is almost past, even in our own country, when thirdrate men can find a place as teachers because they are unfit for everything else. We wish to see brains and learning, combined with eneroy and immense working power, in the professor's chair; but, above all, we wish to see that high and chivalrous spirit which causes one to pursue his idea in spite of all difficulties, to work at th problems of nature with the approval of his own conscience and not of men before him.

The whole universe is before us to study. The greatest labour of the greatest minds bave only given us a few pearls; and yet the limitless ocean, with its hidien deuths filled with diamonds and precious stones, is before us. The problem of the universe is yet unsolved, and the mystery involved in one single atom yet eludes us. The field of research only opens wider and wider as we advance, and our minds are lost in wonder and astonishment at the grandeur and beauty unfolded before us. Shall we help in this grand work, or not? Shall our country do its share, or shall it still live in the almshouse of the world?

\section{CONTENTS}

PAGE

Science Worthies, XXII.--Arthur Cayley. By Prof. George Salmon, F.R.S. (With Steel Plate Engraving).

Bentham and Hooker's "Genera Plantarum." By Ern. Cosson.

Letters to the Editor:-

"The Red Spot upon Jupiter.-A. Riccò ; Stanley; William Mackie ; J. Starkie Gardner (With Diagram)

"Zoology at the Fisheries Exhibition."-The Writer of the Article

A Complete Solar Rainbow.- $\dot{C}$. M. Ingleby Flint Flakes Replaced.-Worthington G. Smith (With Diagrams)

Notes on the Post.Glacial Geology of the Country around Southport. By C. E. de Rance . . . . The British Association :-

Inaugural Address by Arthur Cayley, M.A., D.C.L., LL.D., F.R.S., Sadlerian Professor of Pure Mathematics in the University of Cambridge, President .

Section A-Mathematical and Physical-Opening Address by Prof. Olaus Henrici, Ph.D., F.R.S., President of the Section

Section B-Chemical Science-Opening Address by J. H. Gladstone, Ph.D., F.R.S., V.P.C.S., President of the Section.

Section C-Geology-Opening Address by Prof. W. C. Williamson, LL.D., F.R.S., President of the Section

A Plea for Pure Science. By Prof, H. A. Rowland 